Article

\title{
Expanding Policy for Biodegradable Plastic Products and Market Dynamics of Bio-Based Plastics: Challenges and Opportunities
}

\author{
Taofeeq D. Moshood (D), Gusman Nawanir (D), Fatimah Mahmud *, Fazeeda Mohamad (D), Mohd Hanafiah Ahmad \\ and Airin Abdul Ghani
}

check for updates

Citation: Moshood, T.D.; Nawanir, G.; Mahmud, F.; Mohamad, F.; Ahmad, M.H.; Abdul Ghani, A. Expanding Policy for Biodegradable Plastic Products and Market Dynamics of Bio-Based Plastics Challenges and Opportunities. Sustainability 2021, 13, 6170. https://doi.org/10.3390/su13116170

Academic Editor: Elena Rada

Received: 11 May 2021

Accepted: 25 May 2021

Published: 30 May 2021

Publisher's Note: MDPI stays neutral with regard to jurisdictional claims in published maps and institutional affiliations.

Copyright: (c) 2021 by the authors. Licensee MDPI, Basel, Switzerland. This article is an open access article distributed under the terms and conditions of the Creative Commons Attribution (CC BY) license (https:/ / creativecommons.org/licenses/by/ $4.0 /)$.
Faculty of Industrial Management, Universiti Malaysia Pahang, Gambang 26300, Malaysia; taofeeqmoshood@gmail.com (T.D.M.); gusman@ump.edu.my (G.N.); fazeedamohamad@ump.edu.my (F.M.); hanafiah@ump.edu.my (M.H.A.); airin@ump.edu.my (A.A.G.)

* Correspondence: fatimahm@ump.edu.my

Abstract: Bio-plastics are rapidly growing in popularity, and many new techniques and approaches are emerging as a result of intensive research and development (R\&D) activities. Many industries worldwide are installing their new production capability. Bio-plastics have attracted political leaders interest, especially in light of the evolving bio-economic orientation, through their use of renewable resources and their effects on sustainable growth. Related market determinants are defined, classified, and used as a base for their own estimates. The evolution of global production capacity is modeled annually for the timeframe up to 2030 by applying a system dynamics strategy. For a long-term forecast to catch the inherent volatility, various scenarios are identified and added to the model to represent different trends in the price of gross domestic product (GDP), oil, and bioplastic feedstock. Thus, our findings show the sensitivity in the macro-economic climate of the bioplastics sector. The simulations are completed by a debate on the regulatory environment and its future effect on industry development at the European level. The findings show considerable potential for development but are vulnerable to political and economic impacts.

Keywords: bio-plastics; plastic policies; biodegradable plastics; regulatory environment bio-economy

\section{Introduction}

The functional and structural characteristics of bioplastic are similar to plastics and are extracted, in whole or in part, from biomass materials [1]. A wide range of polymers is used or produced as bioplastics. Bioplastics have become more advanced in applications, such as manufacturing aerospace parts for extreme environments, beyond the initial plain packaging applications [2]. This involved the invention of novel molecules, the combination of molecules, the quest for novel polymers, and eventually, efforts to produce petro-plastics similar to thermoplastics but using bio-based recycled raw materials.

One percent of the 360 million annually manufactured tons of plastic can currently be listed as bioplastics [3]. In evaluating this part of the industry, one must know that the term organic can indicate different things. Bio-plastics include biologically or biodegradable plastics, bio-based or both described by the official European Bioplastics Industry Association [4]. Specifically, when extracted in part from biomass and biodegradables, products are organic as they can be split into natural water, $\mathrm{CO}_{2}$, and compost by microorganisms within a sufficient period of time [5]. Due to its potential role in developing a truly sustainable and circular bio-economy, this sector has gained popularity in recent years. The market for bioplastics is increasing as a manifestation of a growing consumer environmental consciousness. In particular, this affects the bio-based division [2,5]. Using renewables rather than fossil-based materials, they have an ecological advantage compared with traditional plastics regarding a smaller carbon footprint and reduced resource depletion [6]. They also 
pledge the solution to the rapidly pressing problem of plastic waste in land and sea to the point that they will be biodegradable in natural environments.

Although biodegradable plastics are only in the research process, it is easy to replace oil-based plastics, but this did not happen because the cost of making biodegradable plastics is relatively highly associated with traditional plastics [7]. The majority of plants used to produce bioplastic are usually modified. Due to the intermediate steps, the development of polylactic acid (PLA) is expensive. To begin with, lactic acid is converted into a preplastic shape in the reactor at a high temperature and in a vacuum [8]. Pre-plastic, which is a plastic of a low quality, is divided into PLA building blocks. Even though PLA is known as eco-friendly plastic, multiple process intermediate phases also involve metals and create waste [9]. The achievement of plastic's optimum mechanical properties for its purpose is another significant setback, a problem associated with food packaging, PET bottles, and plastics for general use, e.g., cages, dishes, cutlery, etc. For special applications of electric and thermal conductivity, most polymers lack enough mechanical strength and functionality. Thus, $95 \%$ of polymers combine composites with inorganic/organic additives [8]. No one polymer generally has the necessary properties for some use. Still, the transformation, mixture of these polymers, mixture with polymers, and other substances to form an optimum composite has not been improved. These are much more important than petroleum plastics in the production of bioplastics [10].

At least some materials have attained a level of growth at which they can give (almost) the same technological characteristics as fossil plastics and are thus suitable for several applications [11]. However, the downside is the currently high manufacturing cost, which considerably exceeds the cost of manufacturing conventional plastics. The overall environmental balance is mixed, at least with the new generation of energy from food plants used in bioplastic manufacturing, with possible competition for food production and substantive pollution from land use and processing [8]. There is also a potential rivalry with food production. How the market for bioplastic in the coming years will grow will depend heavily on the growth of traditional plastics prices. The production is also influenced by other considerations such as technical advances, economies of scale, and raw material prices $[12,13]$. Moreover, strategies to promote renewable alternatives to plastics from fossil fuels will dramatically shift bio-plastic demand. Therefore a model must be used to predict potential demand to take most of these variables into consideration [14].

This research provides a summary of the findings and methodologies of scenariobased long-term bioplastic demand forecasts. In doing this, focus of this research was given to the biodegradable plastics branch, which seems to be the most promising field from a sustainable point of view. The development of production capacities for biodegradable bio-based plastics is modeled annually by applying the device dynamics modeling and expanding on traditional approaches by Horvat, Wydra, and Lerch [15]. Three separate economic scenarios have also been developed to catch the inherent volatility of such a long-term forecast. These illustrate the various trends in key backdrop variables such as GDP, crude oil, and bio-plastic feedstock price. This demonstrates the vulnerability to shifts in the macroeconomic climate of the bio-plastics industry. The model was calibrated based on a public database and related literature to the extent practicable. Throughout the context of the existing and possible future European policy frameworks, the simulation findings will later be addressed to illustrate the relevance of creating a supportive policy base for business growth in this sector.

\section{Methodology}

Thornhill, Saunders, and Lewis [16] maintain that a comprehensive literature review starts by selecting suitable keywords for finding and extracting databases' publications and provides a literature study. The purpose of a literature review is to recognize gaps in the literature and information constraints, argues by Tranfield, Denyer, and Smart [17]. Literature analysis also reviews and classifies current research based on core topics and proposals for prospective works [18]. According to these principles, the present thesis 
uses a systemic approach to gather and categorize data and literature based on subject interpretation and recommendations for future studies [19]. In brief, the study followed a four-step process (see Figure 1) with the identification of data, initial data screening, eligibility assessment, and finally, data inclusion. This data collection aims to provide information and guidance for future studies. Data were obtained from the ISI Web of Science and Scopus databases. Several academics have regarded the Scopus database as a credible database [20,21]. Academics have been appreciated by the ISI Web of Science database for high-quality indexing material. This repository has been a credible and high-quality source for many previous studies [22,23].

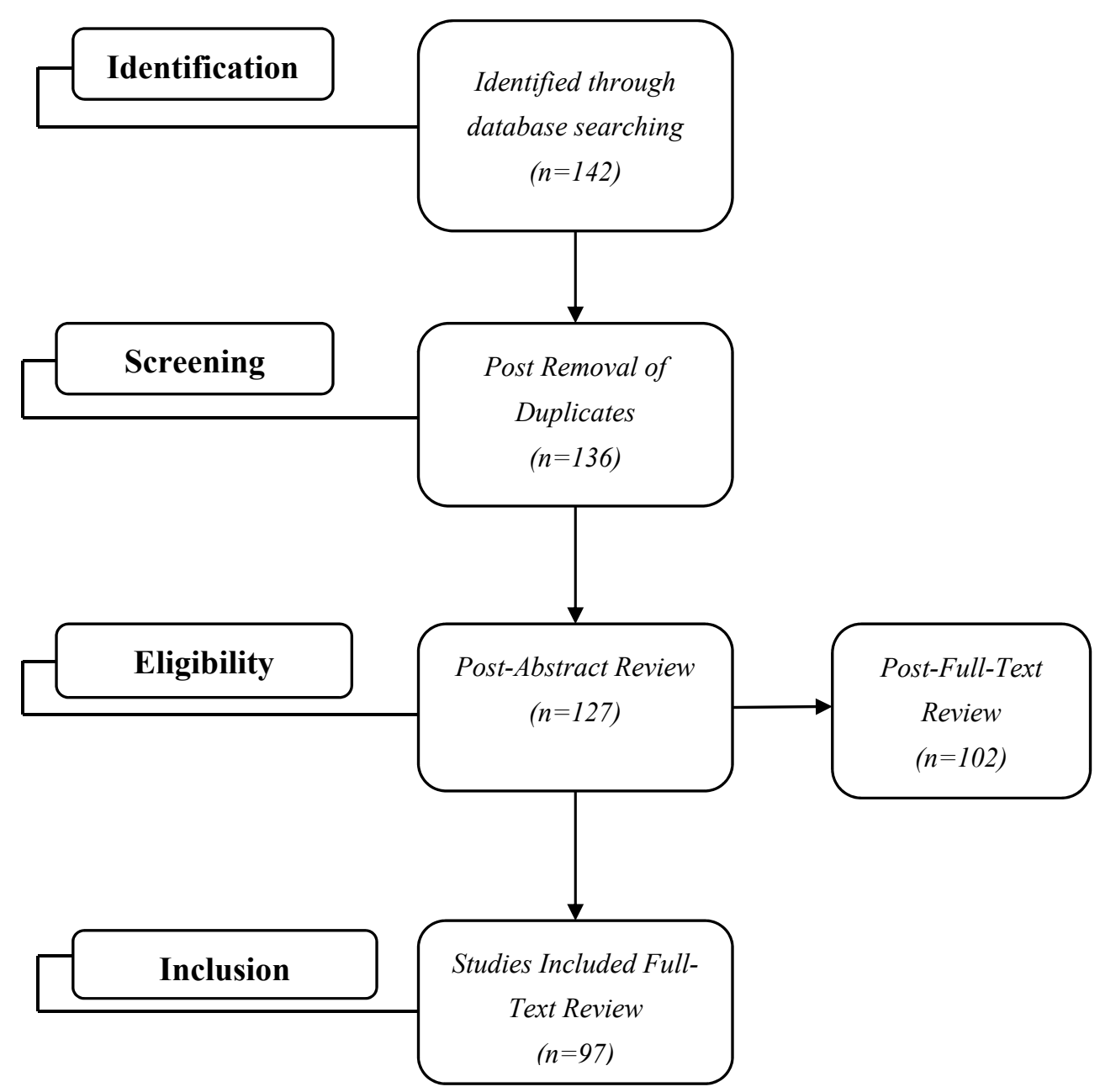

Figure 1. Overview of paper identification, selection, and inclusion process.

\subsection{Identification of the Data}

Articles relevant to the research have been found and extracted using aggregator databases such as Scopus (scopus.com) and publishing databases such as Elsevier (sciencedirect.com), MDPI (https:/ / www.mdpi.com/), Taylor \& Francis (tandfonline.com), Emerald Insight (emeraldinsight.com), and Google Scholar [24]. Initially, the study used keywords such as bioplastics, biodegradable plastics, and plastic policies. The first keywords of the quest were restricted to the document title and the keywords. In the beginning, 2000 articles resulted, using three mixtures of keywords.

\subsection{Screening Initial Data}

The first search results can be obtained using the publications in conference papers, articles, and books, but later omitted excluding articles. The quest has also been limited to articles descriptions and keywords so that books, magazines, and conference proceedings 
can only be excluded from the pile. Consequently, after initial refinement, 142 papers persisted as articles. Finally, 136 documents were picked for the purpose of the review paper after eliminating duplicates.

\subsection{Determining Eligibility}

The keyword used in the search was "bioplastics, biodegradable plastics, and plastic policies" and was limited to the article title only. Only journal articles and conference proceedings were included in the analysis to ensure the academic fields' inclusion under the scrutiny of the most credible materials and publications of exceptional managerial effect [16]. They contained only articles written in the English language. The adoption of the Kyoto Protocol in 2005 was recognized as a remarkable achievement in global sustainability activities, and sustainability science, with the bulk of sustainability integration research in line with the research objective of this analysis adopting this global initiative [25]. Centred on these main achievements in efficiency, bio-plastics, biodegradable plastics, plastic policies, sustainability management, and collecting state-of-the-art publications, this analysis's quest date was set from 2003 to 2021.

\subsection{The Inclusion of the Data}

The analysis confirmed the credible sources of the results. These databases are also generalizable as they index journals from other large databases, including Science Direct, Taylor \& Francis, Elsevier, Springer, Emerald, Wiley, and many more. On the other hand, the data could come from a much more credible source to present observations and possible directions [19]. Many recent researches summarized the data for subjective judgment analysis $[20,21]$. Each stage of the evaluation phase is organized around the sections of Processes, Findings, and Discussion, allowing the reader to further understand how the data are evaluated, following its implications and the resulting data [26]. The papers identified were screened, filtered, and validated for inclusion in the analysis via an iterative selection method after the outlined systematic literature review procedure, as seen in Figure 1.

Duplicates have been excluded as part of this process, eligibility has been verified from abstracts, and the complete content of an outstanding paper has been checked in the context of the study issues for the final judgment regarding the physical internet areas under examination [27]. As per the systematic literature review protocol for this study, the 97 papers were screened and verified as valid.

\section{Overview of the Bio-Based Economy}

At the beginning of the 21st century, bio-based economies were first introduced as a policy framework within the Organisation for Economic Co-operation and Development (OECD). It connected progress in biotechnologies to creativity and green growth by using renewable biological capital and advanced bioprocesses to produce biotechnology on an industrial scale, in the first place for sustainable goods, works, and profits [28]. In 2009 , the OECD noted that the bio-economy could be seen as an environment in which biotechnology contributes significantly to economic production [29]. Towards Green Growth recommended that policymakers find policies that could lead to greener growth's most effective change. Many countries are already working towards national policies for the bio-economy $[12,30,31]$. The European Commission, for instance, announced its future view in the study on innovation for sustainable development, a bio-economy for Europe, in February 2012 [5].

Sustainable primary production, food manufacturing, industrial biotech, and bioproducts are projected to generate considerable growth under this strategy [32]. This will also contribute to new biological industries, transform traditional industries, and open up new organic goods opportunities. At the beginning of 2012, the US government unveiled a blueprint for the national bio-economy with two stated purposes: Setting strategic targets to contribute to the realization and early accomplishments of the American bio-economy's 
full potential for those goals. It foresees an unforeseen future, two classes of new materials: (i) Liquid fuel made directly from $\mathrm{CO}_{2}$, ready to be burned and (ii) biodegradable plastics made not from petroleum but organic biomass [5]. The use of plastics has been omnipresent. Today, 20 times more plastic than 50 years ago is made, and plastics' global production has exceeded and continues to expand. However, most of this substance is extracted from oil and the oxidation of synthetic plastics (e.g., by incineration) emanating carbon dioxide from fossil fuels into the atmosphere for thousands of years [33].

On the other hand, bio-plastics rely on renewable energy, and the carbon dioxide capture and release periods have been relatively short. In concept, bio-plastics are not recent however, after the Second World War, the discovery of vast oil reserves stopped progress in their production when the prices of fossil plastics did not compete with them [5,34]. Today, compared with petro-plastics, the overall production volume for bioplastics is minimal, which has been researched and developed over several decades to improve its product quality and efficiency. Biological plastics remain in the testing process for many decades or so. Due to the comparatively low price of crude oil, it was challenging to create bio-built plastics on the market [35]. This century has seen several significant shifts in the research and development of these new plastics and emerging new applications and molecules.

This fast development of the bioplastic industry has been motivated by many factors. There is a mix of natural, economic, and social advantages offered by bioplastics at a time when crude oil prices appear high and emerging from a significant economic recession [36]. Bio-plastics only have limited exposure to the whole plastics industry but are rising quite quickly. Politicians could have difficulty with this case. Fast growth will also lead to political development [37]. Therefore, it would be time for policymakers to provide a paper showing the variety of bio-plastics being produced and the types of policies implemented in support of the emerging sector [38]. This study hopes to meet this need. The industry's great catalyst was the shift from biodegradables to "drop-in" replacements of the great oil-based plastic products dominating the market, on which we depend so greatly today $[10,39]$. This is usually used for basic packaging applications. The production of bio-based polyethylene (PET) bottles for carbonated beverages is a striking example [40].

Combining bio-based material and the opportunity to access existing recycling facilities makes an environmental and economic proposal very appealing. Bioplastics are also growing in engineering applications [37]. However, it is evident that there has been little support for bioplastics compared to biofuels. However, all biofuel categories aim to achieve common political objectives [41]. In reality, proof exists that bioplastics generate more jobs and have more benefits than biofuels. There is no international funding trend for bioplastics, except that there has been widespread exposure to the niche strategy of banking single-use carry bags. These niche policies would not encourage large-scale production and consumer uptake investment than biofuels' main policies [42]. Bioplastics also have enormous challenges to tackle. In the form of the holistic bio-economy policies, the use of intelligent policy mixtures aimed at developing bioplastics through their entire "cradle-to-grave" life cycle and in conjunction with other organic materials, in particular biofuels, can be considered [43]. A better commodity category than plastics would be hard to conceive. In the future, plastics will compete for crude oil with other applications, thanks to their own popularity. More significant support for policies would now simplify the subsequent transformations from fossil to bio-based energy.

\section{Existing Projections for the Bioplastic Market}

A variety of publications have presented the bioplastic industry with forecasts. An annual report on the bio-plastics sector's progress, published by European Bioplastics and the Institutes of Bioplastics and Biocomposites (IFBB), also provides projections on international bio-plastics rise production capacity. Although the most recent European Bio-plastics study demonstrates global capability growth in the next five years (2020-2024), the current IFBB report contains only the projected 2023 values. Both studies include biodegradable plastics and bio-based predictions. Figure 2 below shows the growth of 
bio-based and biodegradable plastics production capacity for 2014-2024, showing the forecast values. The figure illustrates the estimates in the European Bioplastics [3] survey on the one side and in the IFBB [44] (2019) on the other. Note that the IFBB adds only the four-year forecast value in its annual reports and does not change any forecast values. Thus, the chart reports only the prediction values for 2023.

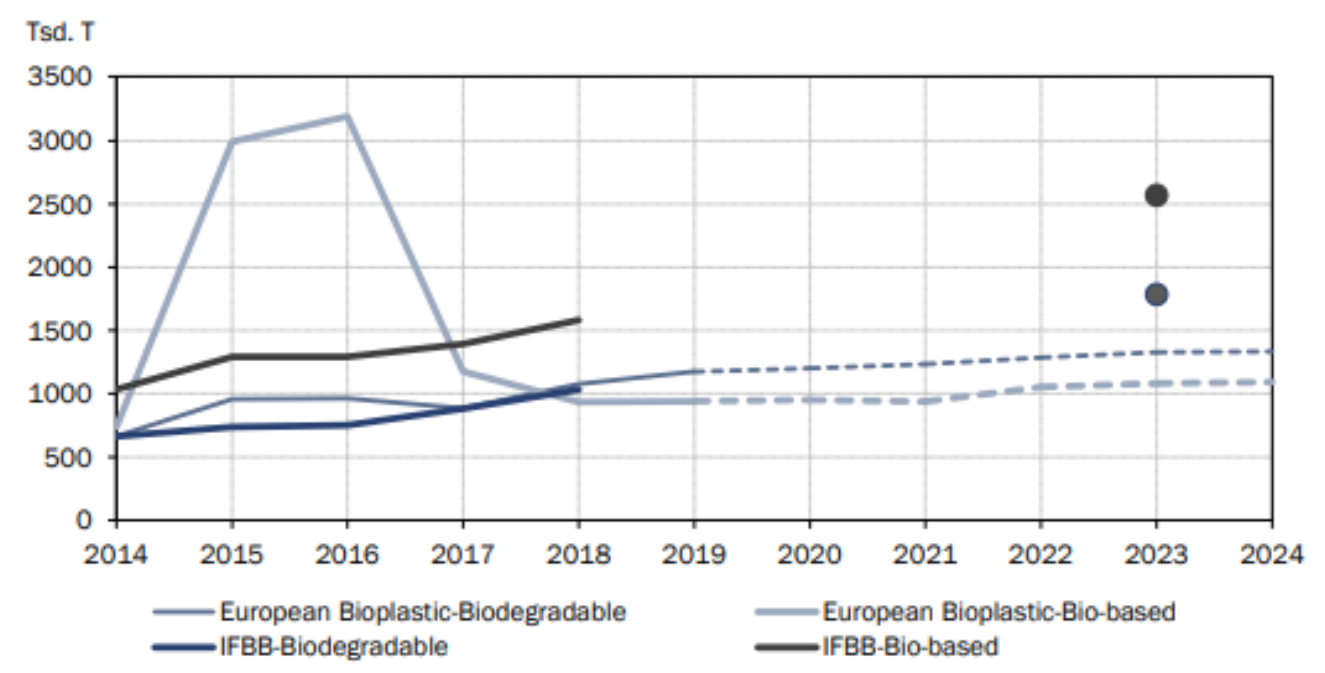

Figure 2. Global production capacities for bioplastics. Source: European Bioplastics [3] (2019) and IFBB [44] (2019).

It can be shown that there are substantial variations in the historical values and predictive values of both organizations. Both studies take on different rates of development. The 2019 IFBB predictions score considerably higher than those of European bioplastics [44]. For biodegradable plastics, the increase of production capacities between 2018 and 2023 is $23.31 \%$, and for bio-based plastics, it has a growth of $15.85 \%$ on average [2,5]. For bio-based and biodegradable plastics, the overall growth figures for IFBB [44] in 2023 were $72.80 \%$ compared with 2018 and $62.43 \%$, respectively. The IFBB [44] estimates 1.8 million tons of biomass-based plastics production and 2.6 million tons of bio-based plastics for 2023. In contrast, European Bioplastics estimates for biodegradable plastics are 1.3 million metric tons, and for organic plastic, 1.1 million metric tons. The increased production potential of biodegradable plastics relative to bio-based plastics has been attributed by European Bioplastics [3], mainly to substantial growth rates of polyhydroxyalcanoates (PHA).

Unfortunately, no data on the technique employed is included in any article. What model has been used to measure the projections, and the details and effect variables were taken into account remains unknown [45]. Thus, it is unexplained how the ideas differed. The references or the techniques for measuring the historical capacities are not even seen transparently, and even these vary considerably between the two studies.

There are also research papers and technical reports that cover the prediction of future advancements in the bio-plastic market. In a Horvat, Wydra, and Lerch [15] report, for instance, a dynamic systems model simulates three specific growth paths of increasing requirement for bio-based plastics up to 2030. The dynamic systems model captures the interplay of various variables affecting bioplastic manufacturing, such as learning impacts, fossil plastic price, oil prices, feedstock and cost of production, and cost structure. In the production of oil markets and the policy decisions taken, the three scenarios of simulations differentiate. The research discusses a baseline, a high oil price scenario, and a risk-free scenario (including policy measures). The market for bio-based plastics is growing in all three situations, indicating considerably faster growth in the risk-free scenario. Production has doubled in the baseline scenario between 2015 and 2030, and demand has increased by $150 \%$ in the high oil cost scenario [46,47]. The derisory price scenario predicts that by 2030, the demand for bio-based plastics is more than 6 million tons, more than six times the 
demand for 2015. However, in view of existing oil market conditions, the supposed oil price growth expectations for all three situations are relatively high. The oil's supposed price in 2019 and 2020 is substantially higher than the average oil price in the lower price case.

\section{The Socio-Economic Impact of Bio-Plastics}

Plastics have a significant socio-economic impact. In 2018, overall plastics production was 360,000 Mtpa [48], and by 2050 plastics production is expected to reach $600 \mathrm{Mtpa}$ [49]. These estimates exclude discontinuous polyacrylamide gel, reflecting a rise in overall production by about $100 \%$ ( $40 \mathrm{Mtpa}$ ). The annual turnover for 2018 alone was over $€ 360 \mathrm{Bn}$ in Europe, and the demand amounted to about $62 \mathrm{Mtpa}$, paying over $€ 30 \mathrm{Bn}$ in taxes. This is just $17 \%$ of the global plastic volume, followed by Asia and Oceania (51\%) and North America (18\%). Accounting for $30 \%$ of the overall global plastic supply, China is the most significant participant [10].

In certain applications, plastics are used in different industries. The packaging industry is the leading market share in Europe [50]. Plastic packaging is thinner and longer-lasting than the latest options [51]. However, the low durability (typically $<6$ months) of packaging generates considerable waste. The total environmental effects can be minimized by biodegradable packaging.

In the same way, biodegradable plastics (e.g., mulch films) could be used to significantly minimize micro plastic soil [51] for agricultural purposes. Biodegradable plastics would theoretically supplement both these industries (a total of $150 \mathrm{Mtpa}$ ). If biodegradability can be combined with oxo-degradability in the same way, more industries can benefit. In general, over 50 percent of biodegradable plastics' overall supply is expected to take over. Per day in the oceans, there are over 20,000 tons of plastic [12,51]. This is due to waste dumps, shortages of pellets during the logistic phase of pre-products (e.g., transport), and littering; industrial pellets are responsible for economic losses of $€ 70-105 \mathrm{Bn}$ [10]. A quarter remains deposited of the plastic waste collected in Europe (the worldwide deposit rate is higher, between 45 and $75 \%$ on average). This means another $€ 90$ billion a year, based on Europe's plastic turnover ( $€ 360$ billion) [10]. The climate and the economy will reduce these damages. Global gross plastics production in 2019 was just 2.1 million tons, both bio-based and biodegradable. An average 14\% increase in output over four years is estimated. If plastics were to stay stable for the next 10 years, biodegradable plastics would increase to about $2 \%$ of the plastics global industry. A clear summary is given in the 2018 Eunomia report [52] of demand estimates, feedstock's, processes, and market leaders.

The GDP growth, as people traditionally use much more plastics as their average incomes grow, would impact plastics demand. Despite the temporary disruption triggered by the pandemic, the global economy can continue to expand in the following decades. The US market is projected to grow from 44,000 US dollars of purchasing power parity (\$PPP) to 81,000 US dollars and from 30,000 to 60,000 US dollars of purchasing power parity (\$PPP). The growth in the number of combined baselines for China, Indonesia, and India is expected to be about 5-6 of around \$14,000 PPP $(\$ 70,000-84,000)$ [10]. In Asia, economic growth will continue to boost global plastics production. Due to this requirement, most polymers will also be made from fossil fuels (today, over $95 \%$ of plastics are produced from fossil-carbon resources).

Fracking has fueled plastic's manufacture by permitting an expansion in the provision of fossil carbon resources [53]. Simultaneously, just $4-6 \%$ of these tools are used in the world's production and usage of plastics with less energy [54]. If non-renewable carbon supplies are mainly used for plastics, fossil-carbon sources' longevity would at least be 10-fold greater [10]. In this respect, green energy technologies would also rely on manufacturing ability. A model-based research analysis forecasts various scenarios of potential per capita energy demand [55]. The worst-case scenario's worrying outcomes (i.e., on-going GDP rise) include a substantial population satisfaction usage of both fossil fuel reserves and clean energy growth. In that case, the removal of energy from petroleum will prevent petrol-based biodegradable plastics from economic development. The potential 
global market will undoubtedly be satisfied with recycled and plant biodegradable plastic products [10].

Human health and protection are tied to climate change, feedstock choice, and the formation of micro-plastics. Two markers exist for climate change regarding the relationship between extreme temperatures and health [56] or floods [57]. Excessive warming and flooding cause premature mortality and are linked directly to greenhouse gas emissions. It can be shown that natural feedstock (for example, plants) is better, but they do face risks different from petro-based plastics. The main hazards in storage facilities, for example, are inhalations of mould and the self-ignition of biomass. Likewise, if powder biomass is used, dust explosions can happen. Any of the biomass molecules are poisonous, and thus protection studies are required irrespective of their sources. Safe to use, the environmental threat posed to the market by micro-plastics can be reduced by waste reduction, waste improvement, and greater biodegradability.

While the hazards of micro-plastics are becoming more known, consumers will defend preferences for organic goods while at the same time reject the transition in their market conduct [58]. A recent study indicates that a significant driver of biodegradable plastics in contrast to consumer choices could be an industrial revolution. Sadly, "bio-based" cannot be differentiated from "bio diversity" by the average consumer [59]. Sustainable industrial practice education in this context may boost customers' views on plastics. A European Academies' science advisory council (EASAC) report suggests that mutual liability between manufacturers and customers could be brought on by plastic packaging price [10]. However, the amount of biodegradable and biologically-based plastics derived from fossil carbon should not be considered. The price of oil [60] makes it impossible to compete with petro-plastics. It is a correct opportunity for businesses and customers to create environmentally sensitive decisions such as a higher carbon tax [61].

Due to the disturbing volume of debris in the seas, education is crucial [62]. The driving force of plastic littering was established as factors, such as the presence of small/singleuse consumer products (such as individual ketchup sachets in fast-food restaurants) and tourism [51]. A failure to quickly recognize may prevent the proper handling of waste. However, the public throwing of garbage reveals the significant lack of effects of pollution [63]. Given the mismanagement of waste only, Asian countries have been recognized as the world's largest polluters [64]. However, the US and EU are the largest plastic waste producers per capita, offering the "biggest polluters" a distorted perspective. This indicates a lack of adequate waste treatment systems and underlines the waste export sector: Plastic is frequently sent for recycling to developing countries [65]. The world's poorest people gain their livelihoods in waste collections, sorts, and sales from waste disposal sites, streets, and bins [53]. This unfortunate fact can be a reverse engineering of waste management because it offers low profits. However, waste disposal activities can be changed if awareness and employment are enhanced. With a greater understanding of waste and climate change, littering will decrease. Biodegradable and bio-based plastics may have a range of socio-economic factors that are favorably impacted [10].

\section{The Life Cycle of a Bioplastic}

Given the possibility for the replacement in some applications of petro-plastics, this section takes into account the life cycle of a bioplastic, from land use to the processing of the raw materials and final disposal alternatives as these have significant ecological effects on the usage of a bioplastic, for example, it's possible for the extenuation change of climate [66]. A bio-plastics life cycle includes bio-sourced growth, raw material harvesting, biomass processing before bio-refining, fermentation, and processing downstream for plastic purification, subsequent injection or blows moulding to make goods, distribution, usage, and end-of-life choices, and transport at various points in the life cycle. With this life cycle in mind, it is helpful to describe these routinely used words: Recyclable, sustainability, and compostable [67]. 


\subsection{Sustainability}

National policymakers and multilateral agencies are increasingly aware that sustainable growth problems cannot be separated from environmental concerns. In many ways, growth erodes ecological infrastructure, and the destruction of the environment will undermine economic growth [68]. No systematic or normative concept of sustainable development, no ideal tools for calculating sustainable development, and no global agreement on the number of measures used to assess are currently available. Although there are drawbacks, life cycle analyses seem to be the logical choice. Consensus on the required environmental mitigation interventions and social and economic implications appears to be possible at a later stage [69]. Development that meets current needs without sacrificing future generations' capacity to fulfil the needs was described quite simply as the principle of sustainable development. However, such a straightforward description is nearly endless to malt.

The OECD proposed at least two meanings, quite similar to the one described above. Other regards not decreasing economic growth patterns and production that may be affected by the loss of natural resources and environmental degradation. To have economic and social consequences, sustainability extends beyond environmental effects [70]. Many organizations in all industries have adopted wide-ranging objectives for sustainability, including specific impacts due to increased customer responsibility and recognizing their role in achieving sustainable living practices. Most companies regard a sustainable approach as a way to achieve a competitive business edge. However, assessing social effects remains a significant problem as accurate benchmarks are challenging to find [71].

An OECD publication [5] exists that is based on the model for measuring the overall environment and health qualities of a commodity, called the National Institute for Standards and Technology (NIST) of the United States Department of Trade [2,5]. The GBEP recently worked on various cultural, economic, and social well-being indicators [72]. Regarding bioplastics, several large businesses develop market strategies that support bioplastics and solve sustainability [73]. This is hardly shocking because bio-plastics form the fastestgrowing line in the global bio-oriented commodity market. A company's sustainability may be to generate benefits from the environment and social use of bio-plastic, work with social stakeholders to identify and track this benefit and work with providers and consumers to create value for all.

\subsection{Recycling}

Two types of recycling exist for plastics: (1) The replacement after processing, washing, and redistribution of the finished product; and (2) thermoplastics ( $80 \%$ ) of the respondents of the plastic packaging market) after collection may be replenished and re-melted to the same product or some other product [74]. Recycling is an essential solution to many environmental plastics issues, but it is not a straightforward method. Plastics need a greater sorting than, e.g., glass and metals, and differentiation by plastic form are necessary because various plastics appear to distinguish phases when coated, to behave much like oil and water and set in particular layers. The resulting substance is structurally fragile such that such mixtures are usable in minimal recycling applications. The growth of contaminants and colorants can also identify recycling issues [75]. Moreover, the recovered plastic cannot be recycled due to improved properties, and melting temperatures in biodegradable plastics merged with petro-plastics. In fact, recycling plastics is not easy despite a simplistic and intuitive allure.

\subsection{Compostable}

Solid material will be called compostable if it is fully converted to particles and biomass within a given period under prescribed conditions in a composting method [76]. Its decline leads to compost-a natural fertilizer that can contribute to soil restoration, weed control, miniaturization, and soil erosion control. 


\section{Impact Factors on Biodegradable Plastics Productions}

The difficulties in planning the growth of biodegradable plastics prices in the future lies in the many factors that influence demand and in quantifying these factors on the other. Complexity is also present in the production of effect variables. In the four affect groups as presented in Figure 3, the major effect variables can be divided:

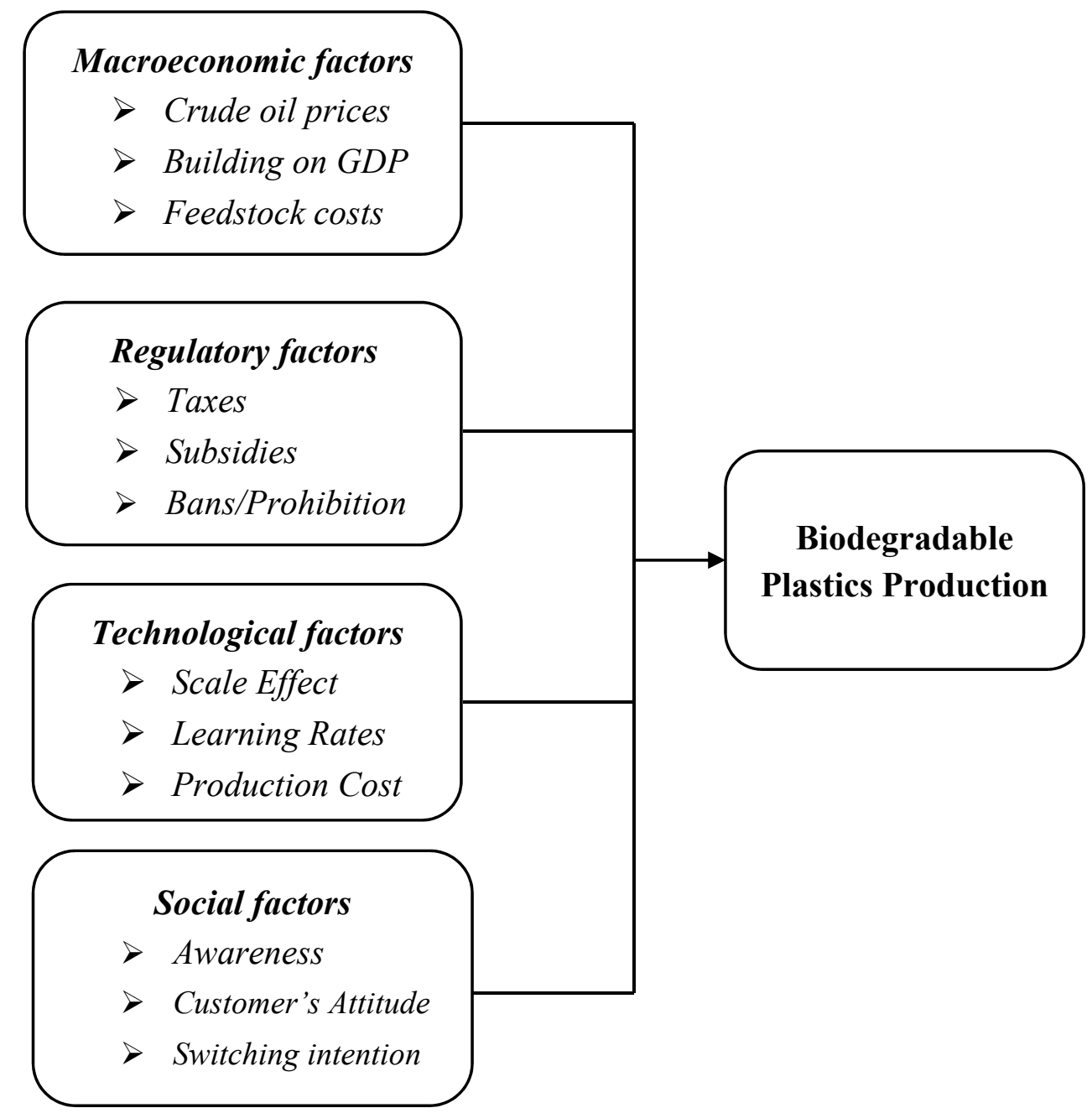

Figure 3. Factors influencing demand for biodegradable plastics.

\subsection{Macroeconomic Factors}

Crude oil prices: Crude oil prices have a significant impact on the growth of demand for bioplastics. The price depends on the oil price production since traditional plastics are mainly made from crude oil. Bio-plastics have become more appealing than a replacement with high oil price and increase fossil plastics costs. A spike in the price of oil would also result in increased demand for bioplastics.

Building on the GDP: An increase in GDP will increase plastics production and growth and increase bio-plastic consumption. If higher-income market players invest higher costs on environmental solutions, this will further fuel demand for bioplastics.

Feedstock costs: The cost of bioplastics production depends heavily on feedstock price growth. At this time, the primary production of bioplastics is maize starch or sugar cane. If maize or sugar prices increase, production costs, and therefore, bio-plastic prices will also rise. In exchange, higher prices lead to a drop in bioplastic production. On the international market, the markets for maize and sugar are highly volatile. 


\subsection{Regulatory Factors}

Environmentally sustainable policies initiatives, for example:

Taxes: Taxes on fossil-based goods could contribute to a rise in the price of traditional plastics. This would lower bioplastic costs in contrast and thereby raise the market for bioplastics.

Subsidies: By means of government incentives, bioplastic manufacturers may sell their goods at lower prices, thus enhancing demand.

Bans/Prohibition: State prohibition of fossil plastics will reinforce the market for bioplastic goods. However, bioplastic goods may still be banned if the bans extend to some form of plastic, and standards will decline.

\subsection{Technological Factors}

All the factors reducing the costs of the manufacture of bioplastics:

Technical development and learning effects: More successful processing methods could be built over time, and the learning effects could lead to a lower cost.

Economies of scale: Businesses can take advantage of cost advantages and produce more revenue at slightly lower (unit) costs by expanding production volume for bioplastics. Currently, bioplastic manufacturing volumes are comparatively low, with production costs being high.

\subsection{Social Factors}

Awareness: Customers' desire to pay for organic goods grows as awareness of natural resources and environmental conservation rises. This will have a positive impact on bio-plastic production.

The different influence factors are, as discussed above, difficult to measure to use in a system for the projection of demand for bioplastics. The knowledge on the reliance on bioplastic requirements is obtained from a time variety of related data for the price of crude oil, feedstock costs, and GDP. As there is also a high level of confusion in the potential implementation of these factors, several technological prospects are being developed throughout the literature and throughout this article [47]. It is also difficult to quantify policy actions that can be imposed into the future, as several policy interventions have different effects. It is also problem-sensitive that national and international strategies will be implemented, which could, in turn, produce different results. It will be much more challenging to operate the perception effect [77].

\section{Specific Options for the Development of Bioplastics}

\subsection{Mobilizing Resources for Research and Development}

Many research activities have been fragmented, and substantial potential remains in many global systems and undoubtedly around national borders for policy interventions to eliminate overlap and generate critical mass. There are also many, if not most domestic innovation structures [47]. This is definitely true of bio-plastics, which have weak relations between scientific efforts and policy processes intended to promote activities in other parts of the value chain. Although increased government support will benefit, there is potential to leverage private-sector investment in the field of bio-plastics and bio-based products through public-private partnerships (PPP).

\subsection{Supporting Scaling Up Activities}

During the design phase, access to pilot and scale-up facilities should be facilitated to minimize research, industry creation, and marketing length [78]. There are also opportunities to build new technologies and solutions for manufacturers of new bioplastics and future end-users to eventually contribute to a greater commercial drive for bio-plastics. 


\subsection{Investing in Demonstrator Facilities}

The investment in protestors and pre-competitive infrastructure should be encouraged to motivate the creation of bio refineries committed for bio-plastics and biomaterial processing. To boost collaborative efforts and synergies between private and public investors, access to financing for creative installations should be integrated and assisted by industrial policies.

\subsection{Alternative Uses for Feedstock}

The bioenergy and biofuels industry received the highest degree of R\&D funding and good support for experimental and demonstration plants at the industrial production phase (e.g., via quotas, green electricity regulations, and tax incentives). This approach contributes to industry distortions about the supply and cost of feedstock, which in turn disadvantages biomaterials and bioplastics [5,79]. When these benefits and aids make oil markets more appealing, bio-refineries are overwhelmingly energy-oriented. They challenge the critical performance and production capacity of a wider variety of renewable bio-plastic materials. Political approaches that would not favor bioenergy and biofuels production compared to other possible outputs are essential to promote the growth of higher value-added goods and the wider job prospects connected with their broader value chains.

\subsection{Agricultural Land Productivity}

There are opportunities to boost sustainable feedstock productivity, e.g., by increasing yields, reusing reclaimed land, abandoned land usage, and enhanced land development and crop improvement management. Farmers should be incentivized to harvest vast quantities of farm crop waste, not only in bioenergy /biofuel development but also for all industries of the organic economy to ensure that feedstock supplies are provided to biorefinery plants [33]. The United States still has such a scheme-the Biomass Crop Assistance Programme. This program offers rural landholders' payments for the development, production, and supply of biomass feedstock (especially agricultural lignocellulose residues) for biomass conversion plants for heat, energy, organic produce, and advanced biofuels. With this program, infrastructure and logistical capacity building and optimization can be facilitated to mobilize all biomass in an economical and environmentally sustainable way, particularly technological mobilization of agricultural residues, biomass, lignocellulose material, and cellulosic non-food material [80].

\subsection{Alternative Cropping Systems}

In certain regions and countries, it is possible to support the production, optimize land use, and emphasize a sustainable green raw material culture to the bio-based economy of alternative crop systems (e.g., perennial crop formation and short rotation coppices under-utilized soils). A recent study in the US [81] shows that land management practices allow the on-going growth of herbaceous perennial species on marginal soils, non-sturdy yet harvesting fertilization, do not include the release into our environment of high levels of carbon dioxide [79].

\subsection{Public Procurement}

Public procurement is a choice that policymakers can take into account in considering ways of encouraging bio-based product growth [82]. Federal departments choose bio-based materials (including bio-plastics) through the US Bio Preferred Program, for example, when making procurement decisions. If such procurement activities are considered, the public sector may prefer to buy bio-based goods except when:

- They are still not widely available;

- They are accessible at high costs only; or

- They do not deliver the acceptable output standard of the particular application.

Due to its potential influence as a mechanism for demand, there is potential for sharing suitable practices among nations to procure bio-products [34]. Initiatives such 
as the Bio-based Products Lead Market Initiative (EU) constitute concerted efforts to support innovation through the combination of supply and demand-side tools covering standardization, labeling, and certification (defining standards for product performance), law (inventory of industry law), and public procurement (fostering gross domination) (the setting up of an Advisory Group for Bio-based Products).

\subsection{Quotas}

The quota is especially used to facilitate the creation and usage of bioenergy and organic fuels (the use of indicative goals or binding objectives), so the quotas for bioplastics will be created. While setting an objective for bioplastics by itself is difficult considering its scope and application fields [35]. For certain bio-plastics used in some applications or particular industries, time-limited and tapering quotas may be implemented. Quotas in the automobile sector, which increasingly use bio-plastics, may be a clear example of this, particularly polylactic acid.

\subsection{Subsidies and Taxes}

Countries take several direct and indirect steps to promote bio-plastic growth, including fiscal and financial incentives to boost private sector investment. Many countries fund R\&D whether directly (through grants, loans, and subventions) or indirectly (through various R\&D tax incentives), and other programs are also supported [7]. Several countries, especially in Asia, offer lucrative tax reductions for businesses that wish to study and develop in this field, particularly Japan, Malaysia, Singapore, South Korea, and China [83].

\subsection{Standards, Labels, and Consumer Awareness}

Strict standards (e.g., EN 13432, ISO 18606, and EN 14995) can assist customers, waste management agencies, and legislatures to make genuine and verifiable statements about the characteristics of bioplastics (such as biodegradability and composting). Specific and clear international requirements will also be necessary to validate claims on properties such as bio-based biomass, recyclability, and sustainability in the future. Harmonized industry practices and consistent product labeling will allow consumers to choose products by identifying products as organic, renewable raw material, and biodegradable. Product labeling should have accurate and credible information on bioplastic environmental performance [84]. Many different ecological marks are now being used internationally, and there are many different meanings and approval processes. Medium-term harmonization of eco-labels can lead to substantial gains in consumer trust and market uptake. Additional actions such as marketing drives could also enhance knowledge content and public availability on bio-plastic environmental benefits, increasing demand.

\section{Policies and Practices by Country}

This section outlines the strategies that countries use to solve problems relating to bioplastics production and use. Details are also discussed on foreign cooperation actions, such as those carried out in the European Union.

\subsection{Malaysia \\ Bio-Economy Related Policies}

Bio-economy Initiative Malaysia (BIM), a comprehensive strategy to facilitate commercialization of the biotechnology sector, has recently attracted the Malaysian government's attention [85]. Supported by the Malaysia Implementation Council for Biotechnology and launched in November 2011 by the Malaysian prime minister, the BIM will provide the nation with the basis for developing a high-income bio-economy through a viable R\&D and commercialization environment for agriculture, healthcare, and industrial biotechnology in 2020. The fields of action are medical biotechnology, including vaccine manufacturing, medical equipment, and biopharmaceutical; industrial biotechnology, bio-based chemical, and energy technologies; and agricultural biotechnology [86]. The Malaysian government 
allowed the Bio-economy Initiative in the whole biotechnology and associated value chain to have created approximately 20,000 jobs by 2020 [87]. The National Biomass Strategy 2020 sets out how Malaysia should grow new biomass markets to generate higher valueadded economic activity to contribute to national gross revenues and generate professional employment [5].

\subsection{China}

\subsubsection{Bio-Economy Related Policies}

In its 12th five-year strategy for energy conservation and emissions reduction, China has recently included bio-economics to change economic growth methods, create environmentally stable and enabling societies with energy savings, and strengthen sustainable development capabilities [88]. China promised to invest in energy-sparing and low-carbon infrastructure worldwide over the next five years, at more than USD 316 billion. The plan also emphasizes China's bio economy's need to meet major health, farming, and environmental needs. China has already set a goal for carbon intensity reduction, which could also impact the plastics industry for the first time in a five-year strategy [89].

Substantial political and scientific funding for biodegradable plastics is being received in China. A particular equities fund is established by the National Development and Reform Committee. Research is actively undertaken by institutes such as the Chinese Academy of Sciences' Institutes of Physics and Chemistry, the University of Tsinghua, and Sichuan University. The production of polylactic acid (PLA) materials have been promoted by China, too. Overcoming obstacles to investment include the taxes and assistance food rates, allegedly below the world level and even frozen, that has been restricted in China. Bio-based chemical products support various producers' rewards for selected companies in emerging biochemical industries and preferential taxation treatment [5]. Since 2005, a particular program has also promoted biodegradables plastics production and consumption $[5,90]$.

\subsubsection{Overcoming Investment Barriers: Taxes and Subsidies}

Feedstock prices remain controlled in China, reportedly under international standards and often frozen. Organic chemical products' support contains various producers' benefits and favorable tax advantages for selected companies in developing biochemical sectors [5]. In 2005, a particular initiative encouraged biodegradable plastics production and use [5,90].

\subsection{Japan}

Policies Specific to Bioplastics

The Japanese government announced two steps in June 2002, after its adoption by the Kyoto Protocol's Japanese government: The Strategic Biotechnology Scheme and Nippon's Strategy on Biomass (December 2002). The two initiatives aim to promote biomass and reduce fossil fuel use and mitigate global warming by biotechnology use. The strategic biotechnology plan's political aims are to replace natural resource plastics by nearly $20 \%$ ( 2.5 to 3 million tons a year) by 2020. In March 2006, the Biomass Nippon Strategy was revised to stimulate the development and use of biomass cities. The Biomass Nippon Strategy led companies like Toyota and NEC to develop their research and development levels on organic plastics and expand their bio-based material.

Japanese carmaker Toyota plans to transition by 2015 to bio-sourced plastics $20 \%$ of the plastics used by its cars and expects bio-plastics to further meet its company-wide goal of $\mathrm{CO}_{2}$ reductions [5]. A certification program for biomass-based plastic products was developed by the Japan Bio Plastics Association (JBPA) to establish the demand for biomass. To analyze and evaluate these plastics, the organization established guidelines and methodologies. The software contains a brand that users can quickly recognize. The BiomassPla JBPA certificate specified that items containing the logo should weigh $25 \%$ of organic plastic. So far, over 900 organic plastic items have been accredited in Japan in JBPA. The device is founded upon a positive list for all materials, biodegradability guidelines, 
safety clearance of all elements, and no evidence of any harmful consequences for soil based on Japanese industrial standards [2,5].

\subsection{Korea}

Policies Specific to Bioplastics

The Korean government launched in 2012 the "Industrial Biotechnological Promotion Plan" to implement a mid-term to longer-term strategy for the production and deployment of relevant innovations, which would reduce the current reliability of the economy on crude oil. In 2020, this effort was projected to replace $4.8 \%$ of crude oil imports with biochemical production, reduce carbon dioxide emissions by about $10.8 \%$, and generate 43,000 new jobs. Several firms have decided to use organic ingredients in their product lines. Samsung Electronics has created a smartphone that uses a bio-based material externally [2,5]. LG Hausys has developed wallpaper that uses PLA materials. In addition, SK Chemical has developed a thermal-resistive bioplastic component and Hyundai Motors intends to partly substitute internal material with bio-based material in its latest models.

In order to broaden knowledge of bioplastics and support the supply, the Korean Bioplastics Association (KBPA) has set up an authentication scheme for biomass materials. A Biomass Plastic Certification scheme is the identification system for KBPA, which can only be achieved when more than $25 \%$ of a substance is composed of ingredients extracted from bio-mass [2,5]. The Korea Association of Biomaterial Packaging (KBMP) also operates a certification program for bio-plastic products. The Korean government recommends the unification of these two programs. The government also plans to revise a preferred procurement mechanism for authenticated goods for public agencies and develop a trade insurance system to enhance exports.

\subsection{Thailand}

\section{Policies Specific to Bioplastics}

Thailand is a nation rich in biomass with rich capital in the plastics industry and with more than 4000 enterprises. The Thai government, in its pursuit of economic growth and sustainability, has recognized the bio-plastic industry as a strategic industrial sector since 2006 [2,5]. This led to the National Roadmap for Bioplastics development established by the National Innovation Agency in 2008 (Ministry of Science and Technology). The 2008-2012 action plan focuses on four main policy areas:

- Sufficient availability of biomass feedstock;

- Accelerating technological growth and technological cooperation;

- Construction of industry and advanced productions;

- The establishing of sympathetic infrastructure.

\subsection{Linkages with European Policies}

European countries have pledged to a transformation from a linear to a balanced circular economy since the signature of the European Green Agreement, which is aimed at achieving climate neutrality by 2050 . The bio-economy is expected to contribute significantly to the circular economy, providing alternatives to fossil fuels and encouraging sustainable resource-based transformation to an economic environment. Bioplastics can give renewability, biodegradability, or composability advantages as an integral part of the bio-economy [91]. In order to mobilize the member states and promote a transition to a greener and prosperous economy, the European Commission has released strategy and directives.

The Circular Economic Action Plan, already implemented in 2015, was revised by the European Commission in earlier 2020. This included several measures aimed at promoting the transition from a linear economy to a circular one. The two key goals of the Implementation Plan are first to guarantee to preserve as much as possible the value of goods, materials, and services in Europe and secondly to minimize waste production [92]. The Action Plan centres on reducing the use of cheap plastic carrier bags in EU Directive 
2015/720. The Circular Economy Action Plan identifies packaging materials as an essential source of waste and, as such, a vital environmental burden, e.g., unused plastic bags carrying bags [5]. The guideline allows European national governments to reduce their use of lightweight plastic package sacks to minimize the harmful impacts of packaging and packaging waste on the environment. Member states are free to choose appropriate steps of their own to meet these objectives. These activities may include national reduction targets and financial actions such as taxes on prohibitions. This order would not exclude biological or biodegradable plastic bags [93].

Directive 2019/904, in effect since July 2019, provides for the action to meet the plastics strategy's target of reuse or recycling of all plastic packaging by 2030. The guideline stipulates, in particular, a ban on disposable plastic goods, for which there are already substitutes made of non-plastic materials. It will prohibit drinking straws, stirrers, balloons, cups, and food containers in 2021, which are used in the same manner as a cotton swab, plastic cutlery and plate products, and immediate use of polystyrene and products made from oxygen-degrading plastic. The guideline also seeks to increase manufacturers' liability in addition to the prohibitions. Manufacturers must notify their clients of plastic waste's harmful effects and pay for maintenance, transport, and disposal costs of different plastic items [93].

There are no specific policy initiatives to promote the bioplastics sector through the European Commission. The European Commission's overall policy is based on plastics that are recyclable rather than biodegradable. The commission, for example, is pursuing the ambitious objective of reuse and recycling 100\% of plastic bags by 2030. Quantitative goals do not determine the share of bio-based or biodegradable plastics $[2,5]$. Both the benefits and dangers of bioplastics are explicitly stated in the above EU approaches and directives.

On the one hand, bio-plastic goods are regarded as a potential alternative to fossil plastics and thus an essential milestone towards sustainable development. On the other hand, the commission also concerns that the words "bio-based" and "biodegradable" might mislead customers and that these goods may not be disposed of correctly after use. This will worsen the litter issue even for bioplastic items. Therefore, the commission advises labeling bio-plastic items to warn customers of their service and disposure [94].

The commission also draws attention to the difficulties involved with disposing biodegradable plastics. They are not inherently appropriate for home composting and may also lead to recycling issues when combined with traditional plastics. The commission, therefore, believes that a properly operated device is necessary for the separate selection of biodegradable plastics. Policy initiatives aimed at limiting plastic use do not differentiate between plastic products produced on fossil and bio-based products [5]. The prohibition on disposable items is not exempt from biodegradation and bio-based plastics, for example. These interventions may also have much more of a negative effect on bioplastics than a positive one. Nevertheless, the commission sees the potential biodegradable plastics can offer and fosters research and innovation in some applications in this field. Innovations on entirely biodegradable products in fresh and saltwater and harmless to the atmosphere and habitats are primarily in the commission's interests.

The commission, therefore, plans to expand its spending on bioplastics research and development. These EU policies cannot easily predict the potential market for bioplastics. The effect is determined by the form and geographical area of the calculation. A plastics levy, of course, would affect demand differently than a plastic ban [2]. The extent of the effect will also depend on the amount and, more specifically, whether the EU measurements differentiate between bioplastics and traditional plastics (EU) or worldwide. The quantitative impact of such policy interventions on our model results cannot be derived from legal uncertainty. In either case, an increase in EU research and development investments could lead to advances that decrease manufacturing costs and make bioplastic more appealing than traditional plastics. Besides, EU initiatives can be expected to increase 
consumers' concern about plastic waste issues in the future, which could in turn lift demand for bioplastics.

\section{Conclusions}

There are few regulations on bio-plastics worldwide, just as there are few on bioplastics and other materials directly. It is also clear that bioplastics have a relative disadvantage over biofuels as policy reviews are underway in various countries. As a benchmark, the Renewable Energy Policy Network for the 21st century announced in 2009 that 73 countries are targets for bioenergy [5], although only a few countries have comparable bioplastic targets. For example, in each region in America [95], promoting policies for biofuels can be found from farms where biomass is cultivated to final product factory and life choices at many points along value chains, but rarely does this happen for bioplastics.

Due to their ability to meet environmental and economic threats, bioplastics have a role to play within the bio-economy. Any bioplastic needs to be studied on a case-by-case basis, but savings in greenhouse gas emissions seem promising in relation to petro-plastic emissions. Furthermore, the forecasts suggest that bioplastics can produce more jobs than biofuels. New bioplastics will be created, petrochemical plastics will be displaced, and new applications emerge (through improvements in existing bioplastics and the development of new ones). Bio-based thermoplastics are equivalents that operate in the same commodity markets as petro-based thermoplastics. They offer the same end-of-life options. Bio-based PET for carbonated beverages has recently been taken to alter the bio-plastic industry dynamics.

Countries work individually and together to improve the bio-economy and enjoy the expected gains, while attempts are less widespread to promote bio-plastics production. In general, biofuels policy support is much greater than it is for either bio-based plastics or bio-based chemicals. This might make bio-economy production unequal, undermining the use of biomass in bioplastics and organic chemicals. The production and operation of integrated bio-refineries may be limited. Sustainability standards and qualification systems are a way to differentiate bio-based from petro-based plastics on the market. However, sustainability measurements remain a challenge without an appropriate measuring instrument even though many sustainability systems, mostly associated with forest and bioenergy applications, have been developed [96]. A lack of appropriate and harmonized concepts of sustainability and globally agreed methodologies for the sustainability evaluation could complicate the international trade of biomass and bio-based goods with products that are not accepted as such in another country.

Political law will play an essential role in future years, on the other hand. Europe-wide, the emphasis is currently on European plastics and bio-economy strategies. However, the extent to which these tactics can impact consumer penetration of bioplastics in general and biodegradables, in particular, remains somewhat unclear. No specific guidelines or exemptions are laid down in those categories in the current plastic-related directives. This is a prerequisite to measure the political impact of bio-plastics on the production of traditional plastics. One innovative way to incorporate market dynamics farther down the supply chain into the model will be to improve opportunities for improvement. This will allow one to distinguish between the applications of biologically-based biodegradable plastics in different applications and discuss the basic role of application policies (e.g., packaging) in developing various industry segments. Finally, the topic of end-of-life disposal choices for specific products will be engaging in light of measures much farther down the supply chain. This includes awareness of the exercise in the future in the composition, recycling, or incinerating of certain biodegradable plastics, which is another important research field that the Bio Plastics Europe program will pursue.

The growth of the bioplastics industry is expected to be influenced by several policies and policy instruments. This includes agricultural policy, supporting R\&D policies and policies in trade and manufacturing, and structures such as subventions and tax credits, racial quotas, standardization programs, and regulatory actions. The essential character- 
istics and patterns are noticeable across countries: Few countries have directly targeted bioplastics policies. Many countries have policies that encourage biofuels and bioenergy, putting bioplastics at a deficit in the biomass competition. The only widely-used bioplastic strategies concern the use and recycling of plastic sacks. Many nations have research and development programs and innovative policies that can support the bioplastics industry. Several countries make substantial efforts to increase bio-plastics manufacturing capability, but the cost of scaling-up leading facilities is constrained. Public procurement's power to boost industry growth has been realized through large blocks like the USA and the European Union. There is an increasing interest in developing systematic bio-economic policies with the potential for specific bio-plastics initiatives in several countries worldwide.

A transition from biodegradable plastics, which are typically used in basic packaging applications, to "drop-in" replacements for the major oil-based plastics that dominate the market, on which we depend so heavily today, has been a significant driver of the industry's growth. The development of bio-based polyethylene terephthalate (PET) bottles for carbonated beverages is a good example of this. In both environmental and economic terms, the convergence of bio-based material and the opportunity to enter existing recycling infrastructure allows for an appealing proposition. Bioplastics are now being used in more engineering applications. However, as opposed to biofuels, it is clear that funding for bioplastics has been minimal. Despite this, all types of bio-based products tend to achieve the same policy objectives. Indeed, there is evidence that bioplastics provide more jobs and bring value to the economy than biofuels. Except for the niche strategy of banning single-use carrier bags, which has attracted universal coverage, there is no international funding trend for bioplastics.

In comparison to the main policies introduced to biofuels, such niche policies would not encourage the necessary investments for large-scale development and consumer adoption. Bioplastics still have a long way to go to conquer daunting obstacles. There is room for more considered use of intelligent policy blends aimed at the production of bioplastics over their entire cradle-to-grave life cycle, as well as in conjunction with other bio-based goods, especially biofuels in the form of holistic bioeconomy strategies. It is impossible to think of a more competitive substance group than plastics. Plastics' popularity in the future will put them in competition with other applications for crude oil. Transitioning from fossil to bio-based energy would be faster with more current policy support.

The main messages for the decision-makers are: Due to their capacity for addressing environmental and economic problems, bioplastics have a critical part to play in the advancement of the bio-economy. The tradition of preferential treatment of sectors like biofuels, which puts bioplastics at a deficit, could experience reconsideration in the overall sense of designing robust bio-economy policies. Again, there is potential for the more considered use of innovative policy mixes aimed at bioplastic development over their entire cradle-to-grave life cycle, and more work needs to be done at the international level to determine and harmonize standard principles such as sustainability so that the creation of waste is not allowed.

Author Contributions: Conceptualization, T.D.M.; writing-original draft preparation, G.N.; writing-review and editing, F.M. (Fatimah Mahmud), review and editing; F.M. (Fazeeda Mohamad), validation and editing, M.H.A., A.A.G. All authors have read and agreed to the published version of the manuscript.

Funding: We would like to acknowledge the Ministry of Higher Education of Malaysia for providing financial support for this research through the Transdisciplinary Research Grant Scheme (TRGS) number TRGS/1/2018/UMP/01/1 (University reference: RDU191801-5).

Institutional Review Board Statement: Not applicable.

Informed Consent Statement: Not applicable.

Data Availability Statement: Not applicable.

Conflicts of Interest: The authors declare no conflict of interest. 


\section{References}

1. Bhagwat, G.; Gray, K.; Wilson, S.P.; Muniyasamy, S.; Vincent, S.G.T.; Bush, R.; Palanisami, T. Benchmarking bioplastics: A natural step towards a sustainable future. J. Polym. Environ. 2020, 28, 3055-3075. [CrossRef]

2. Niklas, D.; Claudia, W.; Wolf, A. Market Dynamics of Biodegradable Bio-Based Plastics: Projections and Linkages to European Policies; HWWI Research Paper No. 193; Hamburg Institute of International Economics: Hamburg, Germany, 2020.

3. Feedstock Recovery of Post-Industrial and Post-Consumer Polylactide Bioplastics. European Bioplastics Fact Sheet. European Bioplastics: Berlin, Germany, 2010. Available online: http://en.europeanbioplastics.org/wp-content/uploads/2011/04/fs/ FactSheet_\%20Feedstock_Recovery.pdf (accessed on 10 May 2021).

4. Calabrò, P.S.; Grosso, M. Bioplastics and waste management. Waste Manag. 2018, 78, 800-801. [CrossRef] [PubMed]

5. OECD. Policies for Bioplastics in the Context of a Bioeconomy; OECD Science, Technology and Industry Policy Papers, No. 10; OECD Publishing: Paris, France, 2013. [CrossRef]

6. Brizga, J.; Hubacek, K.; Feng, K. The Unintended Side Effects of Bioplastics: Carbon, Land, and Water Footprints. One Earth 2020, 3, 45-53. [CrossRef]

7. Neus, E.; Haddad, S.; Börner, J.; Britz, W. Land use mediated GHG emissions and spillovers from increased bioplastic consumption. Environ. Res. Lett. 2018, 12, 1-19.

8. Abioye, O.P.; Abioye, A.A.; Afolalu, S.A.; Ongbail, S.O. A review of biodegradable plastics in Nigeria. Int. J. Mech. Eng. Technol. 2018, 9, 1172-1185.

9. Polman, E.M.N.; Gruter, G.-J.M.; Parsons, J.R.; Tietema, A. Comparison of the aerobic biodegradation of biopolymers and the corresponding bioplastics: A review. Sci. Total Environ. 2020, 753, 141953. [CrossRef]

10. Filiciotto, L.; Rothenberg, G. Biodegradable Plastics: Standards, Policies, and Impacts. ChemSusChem 2021, 14, 56-72. [CrossRef]

11. Kamaruddin, H.; Ling, S.T.Y.; Hoe, L.I. Externalities of business entities from plastic pollution at Perhentian island, Malaysia. Opción Rev. Cienc. Hum. Soc. 2020, 91, 1380-1404.

12. Geyer, R.; Jambeck, J.; Law, K.L. Production, use, and the fate of all plastics ever made. Sci. Adv. 2017, 7, e1700782. [CrossRef] [PubMed]

13. Dilkes-Hoffman, L.S. Exploring the role of biodegradable plastics. Ph.D. Thesis, The University of Queensland, Brisbane, Australia, 2020.

14. Sinan, M. Bioplastics for sustainable development: General scenario in India. Curr. World Environ. 2020, 15, 24-28. [CrossRef]

15. Horvat, D.; Wydra, S.; Lerch, C.M. Modelling and simulating the dynamics of the European demand for bio-based plastics. Int. J. Simul. Model. 2018, 17, 419-430. [CrossRef]

16. Saunders, M.; Lewis, P.; Thornhill, A. Research Methods for Business Students, 5th ed.; Pearson Education Limited: London, UK; Available online: https: / / iteseerx.ist.psu.edu/viewdoc/download?doi=10.1.1.475.7307\&rep=rep1\&type=pdf (accessed on 10 May 2021).

17. Tranfield, D.; Denyer, D.; Smart, P. Towards a methodology for developing evidence-informed management knowledge by means of a systematic review. Br. J. Manag. 2003, 14, 207-222. [CrossRef]

18. Stefan, S.; Müller, M.; Westhaus, M.; Morana, R. Conducting a literature review-the example of sustainability in supply chains. In Research Methodologies in Supply Chain Management; Springer: Heidelberg, Germany, 2005; pp. 91-106.

19. Tseng, M.-L.; Islam, S.; Karia, N.; Fauzi, F.A.; Afrin, S. A literature review on green supply chain management: Trends and future challenges. Resour. Conserv. Recycl. 2019, 141, 145-162. [CrossRef]

20. Fahimnia, B.; Sarkis, J.; Davarzani, H. Green supply chain management: A review and bibliometric analysis. Int. J. Prod. Econ. 2015, 162, 101-114. [CrossRef]

21. Malviya, R.K.; Kant, R. Green supply chain management (GSCM): A structured literature review and research implications. Benchmarking Int. J. 2015, 22, 1360-1394. [CrossRef]

22. Apriliyanti, I.D.; Alon, I. Bibliometric analysis of absorptive capacity. Int. Bus. Rev. 2017, 26, 896-907. [CrossRef]

23. Moshood, T.D.; Adeleke, A.Q.; Nawanir, G.; Ajibike, W.A.; Shittu, R.A. Emerging Challenges and Sustainability of Industry 4.0 Era in the Malaysian Construction Industry. Int. J. Recent Technol. Eng. 2020, 9, 1627-1634. [CrossRef]

24. Moshood, T.; Nawanir, G.; Sorooshian, S.; Mahmud, F.; Adeleke, A. Barriers and Benefits of ICT Adoption in the Nigerian Construction Industry. A Comprehensive Literature Review. Appl. Syst. Innov. 2020, 3, 46. [CrossRef]

25. Rajeev, A.; Pati, R.K.; Padhi, S.S.; Govindan, K. Evolution of sustainability in supply chain management: A literature review. J. Clean. Prod. 2017, 162, 299-314. [CrossRef]

26. Moshood, T.; Adeleke, A.; Nawanir, G.; Mahmud, F. Ranking of human factors affecting contractors' risk attitudes in the Malaysian construction industry. Soc. Sci. Humanit. Open 2020, 2, 100064. [CrossRef]

27. Moher, D.; Shamseer, L.; Clarke, M.; Ghersi, D.; Liberati, A.; Petticrew, M.; Shekelle, P.; Stewart, L.A.; PRISMA-P Group. Preferred reporting items for systematic review and meta-analysis protocols (PRISMA-P) 2015 statement. Syst. Rev. 2015, 4, 1. [CrossRef] [PubMed]

28. OECD. Future Prospects for Industrial Biotechnology; OECD Publishing: Paris, France, 2011; p. 137, ISBN 978-92-64-11956-7.

29. OECD. The Bioeconomy to 2030: Designing a Policy Agenda; OECD Publishing: Paris, France, 2019; ISBN 978-92-64-03853-0.

30. Zalasiewicz, J.; Waters, C.N.; Sul, J.A.I.D.; Corcoran, P.L.; Barnosky, A.D.; Cearreta, A.; Edgeworth, M.; Gałuszka, A.; Jeandel, C.; Leinfelder, R.; et al. The geological cycle of plastics and their use as a stratigraphic indicator of the Anthropocene. Anthropocene 2016, 13, 4-17. [CrossRef] 
31. Aziz, N.A.A.; Lukhman, A.A.; Chubo, J.K.; Daud, D.S.R.A. Public Perception to Littering in Greenspaces: A Case Study in Bintulu, Sarawak, Malaysia. J. Phys. Conf. Ser. 2019, 1358, 012031. [CrossRef]

32. Haddad, S.; Escobar, N.; Britz, W. Economic and environmental implications of a target for bioplastics consumption: A CGE analysis. In Proceedings of the International Association of Agricultural Economists Conference, Vancouver, BC, Canada, 28 July-2 August 2018; 2018; pp. 1-16. [CrossRef]

33. Escobar, N.; Britz, W. Metrics on the sustainability of region-specific bioplastics production, considering global land-use change effects. Resour. Conserv. Recycl. 2021, 167, 105345. [CrossRef]

34. Brodin, M.; Vallejos, M.; Opedal, M.T.; Area, M.C.; Chinga-Carrasco, G. Lignocellulosics as sustainable resources for the production of bioplastics-A review. J. Clean. Prod. 2017, 162, 646-664. [CrossRef]

35. Morone, P.; Tartiu, V.E.; Falcone, P.M. Assessing the potential of biowaste for bioplastics production through social network analysis. J. Clean. Prod. 2015, 90, 43-54. [CrossRef]

36. Siqueira, L.D.V.; Arias, C.I.L.F.; Maniglia, B.C.; Tadini, C.C. Starch-based biodegradable plastics: Methods of production, challenges and future perspectives. Curr. Opin. Food Sci. 2021, 38, 122-130. [CrossRef]

37. Kazuo, M.; Kamini, N.R.; Ikeda, H.; Iefuji, H. Cutinase-like enzyme from the yeast Cryptococcus sp. strain S-2 hydrolyses polylactic acid and other biodegradable plastics. Appl. Environ. Microbiol. 2005, 71, 7548-7550.

38. Andrew, C.; Cowan, J.; Hayes, D.; Dorgan, J.; Inglis, D.; Miles, C.A. Using biodegradable plastics as agricultural mulches. Washington State University Extension Fact Sheet. 2013, FS103E, pp. 1-6. Available online: https://research.libraries.wsu.edu/ xmlui/bitstream/handle/2376/4418/FS103E.pdf?sequence=2 (accessed on 10 May 2021).

39. Chek, M.F.; Kim, S.-Y.; Mori, T.; Tan, H.T.; Sudesh, K.; Hakoshima, T. Asymmetric Open-Closed Dimer Mechanism of Polyhydroxyalkanoate Synthase PhaC. iScience 2020, 23, 101084. [CrossRef] [PubMed]

40. Din, M.I.; Ghaffar, T.; Najeeb, J.; Hussain, Z.; Khalid, R.; Zahid, H. Potential perspectives of biodegradable plastics for food packaging application-review of properties and recent developments. Food Addit. Contam. Part A 2020, 37, 665-680. [CrossRef]

41. Sarieh, M.; Ghomi, E.R.; Shakiba, M.; Shafiei-Navid, S.; Abdouss, M.; Bigham, A.; Khosravi, F.; Ahmadi, Z.; Faraji, M.; Abdouss, H.; et al. The Effect of Poly (Ethylene glycol) Emulation on the Degradation of PLA/Starch Composites. Polymers 2021, 13, 1019. [CrossRef]

42. Shen, M.; Song, B.; Zeng, G.; Zhang, Y.; Huang, W.; Wen, X.; Tang, W. Are biodegradable plastics a promising solution to solve the global plastic pollution? Environ. Pollut. 2020, 263, 114469. [CrossRef]

43. Caroline, O.; Barret, N.; Lemaire, A. How consumers of plastic water bottles are responding to environmental policies? Waste Manag. 2017, 61, 13-27.

44. Biopolymers Facts and Statistics; Institute for Bioplastics and Biocomposites: Hannover, Germany, 2020; Available online: https: / / www.ifbb-hannover.de/files/IfBB/downloads/faltblaetter_broschueren/f+s/Biopolymers-Facts-Statistics-2020.pdf (accessed on 9 May 2021).

45. Elena-Diana, C.; Ghinea, C.; Hlihor, R.M.; Simion, I.M.; Smaranda, C.; Favier, L.; Roşca, M.; Gostin, I.; Gavrilescu, M. Challenges and opportunities in green plastics: An assessment using the ELECTRE decision-aid method. Environ. Eng. Manag. J. 2015, 14, 689-702.

46. Briassoulis, D.; Dejean, C. Critical review of norms and standards for biodegradable agricultural plastics Part I. Biodegradation in soil. J. Polym. Environ. 2010, 18, 384-400. [CrossRef]

47. Rujnić-Sokele, M.; Pilipović, A. Challenges and opportunities of biodegradable plastics: A mini-review. Waste Manag. Res. 2017, 35, 132-140. [CrossRef] [PubMed]

48. European Bioplastics. European Bioplastics e.V. Market. 2019. Available online: https://www.european-bioplastics.org/market/ (accessed on 9 May 2021).

49. European Parliament. A European Strategy for Plastics in a Circular Economy. 2018. Available online: https://www.europarl. europa.eu/doceo/document/TA-8-2018-0352_EN.html (accessed on 9 May 2021).

50. Bernd, B.; Pilz, H. The Impact of Plastic Packaging on Life Cycle Energy Consumption and Greenhouse Gas Emissions in Europe; Denkstatt GmbH: Wien, Austria, 2011.

51. Guo, J.-J.; Huang, X.-P.; Xiang, L.; Wang, Y.-Z.; Li, Y.-W.; Li, H.; Cai, Q.-Y.; Mo, C.-H.; Wong, M.-H. Source, migration and toxicology of microplastics in soil. Environ. Int. 2020, 137, 105263. [CrossRef]

52. Hann, S.; Scholes, R.; Briedis, R.; Kirkevaag, K. Bio-Based and Biodegradable Plastics: An Assessment of the Value Chain for Bio-Based and Biodegradable Plastics in Norway. 2018. Available online: https://www.miljodirektoratet.no/globalassets/ publikasjoner/m1206/m1206.pdf (accessed on 9 May 2021).

53. Henning, W.; Schinkel, J.; Feder, L. Prevention of Plastic Waste in Production and Consumption by Multi-Actor Partnerships; PREVENT Waste Alliance: Bonn, Germany, 2020; Available online: https://prevent-waste.net/wp-content/uploads/2020/07/Prevention_ of_plastic_waste_in_production_and_consumption_final.pdf (accessed on 9 May 2021).

54. Munmaya, M. (Ed.) Encyclopedia of Polymer Applications; CRC Press: Boca Raton, FL, USA, 2018.

55. Capellán-Pérez, I.; Mediavilla, M.; de Castro, C.; Carpintero, Ó.; Miguel, L.J. Fossil fuel depletion and socio-economic scenarios: An integrated approach. Energy 2014, 77, 641-666. [CrossRef]

56. Extreme Temperatures and Health. 2016. Available online: https://www.eea.europa.eu/data-and-maps/indicators/heat-andhealth-2/assessment (accessed on 9 May 2021). 
57. Christopher, B.F.; Barros, V.R. (Eds.) Climate Change 2014-Impacts, Adaptation and Vulnerability: Regional Aspects; Cambridge University Press: Cambridge, UK, 2014.

58. Heidbreder, L.M.; Bablok, I.; Drews, S.; Menzel, C. Tackling the plastic problem: A review on perceptions, behaviours, and interventions. Sci. Total Environ. 2019, 668, 1077-1093. [CrossRef]

59. Sanchez-Vazquez, S.A.; Hailes, H.C.; Evans, J.R.G. Hydrophobic polymers from food waste: Resources and synthesis. Polymer 2013, 53, 627-694. [CrossRef]

60. Ederington, L.H.; Fernando, C.S.; Hoelscher, S.A.; Lee, T.K.; Linn, S.C. A review of the evidence on the relationship between crude oil prices and petroleum product prices. J. Commod. Mark. 2019, 13, 1-15. [CrossRef]

61. Easwaran, N.; Gallagher, K.S.; Koester, S.; Alejo, J.R. Carbon pricing in practice: A review of existing emissions trading systems. Clim. Policy 2018, 18, 967-991.

62. Bollmann, M.; Bosch, T.; Colijn, F.; Ebinghaus, R.; Froese, R.; Güssow, K.; Khalilian, S.; Krastel, S.; Körtzinger, A.; Langenbuch, M.; et al. World Ocean review: Living with the Oceans; Maribus: Hamburg, Germany, 2010; Available online: http: / /aquaticcommons. org/15582/1/WOR1_english.pdf (accessed on 9 May 2021).

63. Hannah, R.; Roser, M. Plastic Pollution. Our World in Data. 2018. Available online: https://ourworldindata.org/plasticpollution?utm_source=newsletter (accessed on 9 May 2021).

64. Jambeck, J.R.; Geyer, R.; Wilcox, C.; Siegler, T.R.; Perryman, M.; Andrady, A.; Narayan, R.; Law, K.L. Plastic waste inputs from land into the ocean. Science 2015, 347, 768-771. [CrossRef] [PubMed]

65. Möller, J.N.; Löder, M.G.J.; Laforsch, C. Finding microplastics in soils: A review of analytical methods. Environ. Sci. Technol. 2020, 54, 2078-2090. [CrossRef]

66. Kakadellis, S.; Harris, Z.M. Don't scrap the waste: The need for broader system boundaries in bioplastic food packaging life-cycle assessment-a critical review. J. Clean. Prod. 2020, 274, 122831. [CrossRef]

67. Beckstrom, B.D.; Wilson, M.H.; Crocker, M.; Quinn, J.C. Bioplastic feedstock production from microalgae with fuel co-products: A techno-economic and life cycle impact assessment. Algal Res. 2020, 46, 101769. [CrossRef]

68. Ramani, N.; Balakrishnan, S. Drivers for biodegradable/compostable plastics \& role of composting in waste management \& sustainable agriculture. In Proceedings of the Symposium Proceedings. Biological Methods of Waste Treatment and Management in South India, Chennai, India, 15 February 2007; Tharakan, J., Ed.; United States Educational Foundation in India: New Delhi, India, 2007; pp. 24-29.

69. Kim, H.; Lee, S.; Ahn, Y.; Lee, J.; Won, W. Sustainable production of bioplastics from lignocellulosic biomass: Techno-economic analysis and life-cycle assessment. ACS Sustain. Chem. Eng. 2020, 8, 12419-12429. [CrossRef]

70. Sompit, P.; Malakul, P.; Nithitanakul, M.; Papong, S.; Wenunun, P.; Likitsupin, T.W.; Chom-In, R. Trungkavashirakun, and E. Sarobol. Life cycle management of bioplastics for a sustainable future in Thailand: Sa-med Island model. Chem. Eng. Trans. 2012, $29,265-270$.

71. Bishop, G.; Styles, D.; Lens, P.N. Environmental performance comparison of bioplastics and petrochemical plastics: A review of life cycle assessment (LCA) methodological decisions. Resour. Conserv. Recycl. 2021, 168, 105451. [CrossRef]

72. GBEP. The Global Bioenergy Partnership Sustainability Indicators for Bioenergy; GBEP Secretariat, Food and Agricultural Organisation of the United Nations (FAO): Rome, Italy, 2011; p. 211.

73. Iles, A.; Martin, A.N. Expanding bioplastics production: Sustainable business innovation in the chemical industry. J. Clean. Prod. 2013, 45, 38-49. [CrossRef]

74. Hopewell, J.; Dvorak, R.; Kosior, E. Plastics recycling: Challenges and opportunities. Philos. Trans. R. Soc. B Biol. Sci. 2009, 364, 2115-2126. [CrossRef] [PubMed]

75. Dilkes-Hoffman, L.; Pratt, S.; Lant, P.; Laycock, B. The role of biodegradable plastic in solving plastic solid waste accumulation. In Plastics to Energy; William Andrew Publishing: Amsterdam, The Netherlands, 2019; pp. 469-505.

76. Papong, S.; Malakul, P.; Trungkavashirakun, R.; Wenunun, P.; Chom-In, T.; Nithitanakul, M.; Sarobol, E. Comparative assessment of the environmental profile of PLA and PET drinking water bottles from a life cycle perspective. J. Clean. Prod. 2014, 65, 539-550. [CrossRef]

77. Haider, T.P.; Völker, C.; Kramm, J.; Landfester, K.; Wurm, F.R. Plastics of the future? The impact of biodegradable polymers on the environment and on society. Angew. Chem. Int. Ed. 2019, 58, 50-62. [CrossRef]

78. Changwichan, K.; Silalertruksa, T.; Gheewala, S.H. Eco-efficiency assessment of bioplastics production systems and end-of-life options. Sustainability 2018, 10, 952. [CrossRef]

79. Van Dongen, P.; Tak, H.; Claassen, E. Policies and patenting to stimulate the biotechnology sector: Evidence from The Netherlands. Sci. Public Policy 2019, 46, 136-147. [CrossRef]

80. Ni, Y.; Richter, G.M.; Mwabonje, O.N.; Qi, A.; Patel, M.K.; Woods, J. Novel integrated agricultural land management approach provides sustainable biomass feedstocks for bioplastics and supports the UK's 'net-zero target. Environ. Res. Lett. 2020, 16, 014023. [CrossRef]

81. Gelfand, I.; Sahajpal, R.; Zhang, X.; Izaurralde, R.C.; Gross, K.L.; Robertson, G.P. Sustainable bioenergy production from marginal lands in the US Midwest. Nature 2013, 493, 514-517. [CrossRef]

82. Gulie, M.M. Green Public Procurement in Romania. Quality-Access to Success 2019, 20, $295-301$.

83. Pazienza, P.; De Lucia, C. For a new plastics economy in agriculture: Policy reflections on the EU strategy from a local perspective. J. Clean. Prod. 2020, 253, 119844. [CrossRef] 
84. Philp, J.C.; Ritchie, R.J.; Guy, K. Biobased plastics in a bioeconomy. Trends Biotechnol. 2013, 31, 65-67. [CrossRef] [PubMed]

85. Oguntuase, O.J. Bioeconomy for sustainable development in Nigeria: Lessons from international experiences. J. Res. Rev. Sci. 2018, 4, 97-104. [CrossRef]

86. Kifordu, A.A.; Adetunji, C.O.; Odiwo, W.O.; Mishra, R.S. Food Innovation and Sustainable Development: A Bioeconomics Perception. In Innovations in Food Technology; Springer: Singapore, 2020; pp. 3-16.

87. MOSTI. Bioeconomy Initiative Malaysia, Ministry of Science, Technology and Innovation. 2011. Available online: www.biotek. gov.my/bioeconomy/index.php (accessed on 28 November 2020).

88. Vargas-Hernández, J.G. Bio-economy at the crossroads of sustainable development. In Advanced Integrated Approaches to Environmental Economics and Policy: Emerging Research and Opportunities; IGI Global: Hershey, PA, USA, 2020; pp. $23-48$.

89. MEP. The 12th Five-Year Plan for Energy Saving and Emission Reduction, Ministry of Environmental Protection of the People's Republic of China. 2012. Available online: http:/ / english.mep.gov.cn/News_service/infocus/201207/t20120717_233562.htm (accessed on 15 January 2021).

90. Consult, Clever. The Knowledge-Based Bio-Economy in Europe: Achievements and Challenges. Clever Consult: Brussels, Belgium, 2010. Available online: http://cleverconsult.eu/cleversafe/wp-content/uploads/2010/09/KBBE_A4_1_Full-report_ final.pdf (accessed on 21 January 2021).

91. Viaggi, D. Towards an economics of the bioeconomy: Four years later. Bio-Based Appl. Econ. 2016, 5, 101-112.

92. European Commission. A New Circular Economy Action Plan for a Cleaner and More Competitive Europe, Brussels, 11.3.2020. COM (2020) 98 final.2020. Available online: https:/ / eur-lex.europa.eu/legal-content/EN/TXT/PDF/?uri=CELEX:52020DC009 $8 \&$ from $=\mathrm{EN}$ (accessed on 17 February 2021).

93. European Parliament and Council. EU Directive 2019/904 of the European Parliament and of the Council of 5 June 2019 on the Reduction of the Impact of Certain Plastic Products on the Environment. 2019. Available online: https:/ / eur-lex.europa.eu/legalcontent/EN/TXT/PDF/?uri=CELEX:32019L0904\&from=DE (accessed on 18 January 2021).

94. European Parliament and Council. EU Directive 2018/851 of the European Parliament and of the Council of 30 May 2018 amending Directive 2008/98/EC on Waste. 2018. Available online: https:/ / eur-lex.europa.eu/legal-content/EN/TXT/PDF/?uri=CELEX: 32018L0851\&from=DE (accessed on 15 January 2021).

95. Steenblik, R. Biofuels at What Cost? Government Support for Ethanol and Biodiesel in Selected OECD Countries A Synthesis of Reports Addressing Subsidies for Biofuels in Australia, Canada, the European Union, Switzerland and the United States; No. D-1589; The Global Subsidies Initiative, GSI: Geneva, Switzerland, 2007.

96. Saarela, S.-R. From pure science to participatory knowledge production? Researchers' perceptions on the science-policy interface in bioenergy policy. Sci. Public Policy 2019, 46, 81-90. [CrossRef] 